\title{
GAS EXCHANGE IN DIFFERENT VARIETIES OF BANANA PRATA IN SEMI-ARID ENVIRONMENT ${ }^{1}$
}

\section{ALESSANDRO DE MAGALHÃES ARANTES ${ }^{2}$, SÉRGIO LUIZ RODRIGUES DONATO², DALMO LOPES DE SIQUEIRA ${ }^{3}$, EUGÊNIO FERREIRA COELHO ${ }^{4}$ \\ TÂNIA SANTOS SILVA ${ }^{2}$}

\begin{abstract}
This study aimed to evaluate gas exchange of banana Prata in two production cycles in semiarid environment. Six cultivars were used as treatments arranged into a completely randomized design with five replications and four plants per plot. For physiological characteristics, it was considered a factorial arrangement of $6 \times 14 \times 2$, six cultivars, 14 periods (months), two readings, $8 \mathrm{~h}$ and $14 \mathrm{~h}$ in each period. The rates of gas exchange, the carboxylation efficiency and the instantaneous efficiency of water use were higher at $8 \mathrm{~h}$ and lower at $14 \mathrm{~h}$, with rare exceptions. The 'BRS Platina' had a higher leaf temperature, higher transpiration and lower water use efficiency. 'Prata-Anã', 'FHIA-18' and 'Maravilha' expressed lower leaf temperature and lower transpiration. The 'Maravilha' is the most efficient in water use. Transpiration increases linearly with the leaf temperature, while the instantaneous efficiency of water use decreases linearly.
\end{abstract}

Index terms: Musa spp., $\mathrm{AAB}$ and $\mathrm{AAAB}$, physiological variables.

\section{TROCAS GASOSAS EM DIFERENTES CULTIVARES DE BANANEIRAS TIPO PRATA EM AMBIENTE SEMIÁRIDO}

RESUMO - Objetivou-se com o presente trabalho avaliar as trocas gasosas de bananeiras tipo Prata, em dois ciclos de produção em ambiente semiárido. Utilizaram-se seis cultivares como tratamentos dispostos em um delineamento experimental inteiramente casualizado, com cinco repetições e quatro plantas úteis por parcela. Para as características fisiológicas, considerou-se um arranjo em esquema fatorial $6 \times 14 \times 2$, seis cultivares, 14 épocas de avaliação (meses) e dois horários de leitura (8h e 14h), em cada época. As taxas de trocas gasosas, a eficiência de carboxilação e a eficiência instantânea do uso da água foram maiores às $8 \mathrm{~h}$ e menores às $14 \mathrm{~h}$, com raras exceções. A 'BRS Platina' apresentou maior temperatura foliar, maior transpiração e menor eficiência de uso da água. 'Prata-Anã', 'FHIA-18' e 'Maravilha' expressaram menor temperatura foliar e menor transpiração. A 'Maravilha' é mais eficiente no uso da água. A transpiração aumenta de maneira linear com o aumento da temperatura foliar, enquanto a eficiência instantânea do uso da água decresce linearmente.

Termos para indexação: Musa spp., AAB e AAAB, variáveis fisiológicas.

1(Trabalho 076-15). Recebido em: 09-03-2015. Aceito para publicação em: 17-08-2015.

${ }^{2}$ Instituto Federal Baiano - Campus Guanambi, Distrito de Ceraima, Caixa Postal 009, 46430-000, Guanambi - BA, E-mail: alessandro. arantes@guanambi.ifbaiano.edu.br; sergio.donato@guanambi.ifbaiano.edu.br; tania_ifbaiano@hotmail.com

${ }^{3}$ Departamento de Fitotecnia, Universidade Federal de Viçosa, Avenida P. H. Rolfs, 36570-900, Viçosa - MG, E-mail: siqueira@ufv.br ${ }^{4}$ Embrapa Mandioca e Fruticultura, Rua Embrapa s/n, Caixa Postal 007, CEP 44380-000, Cruz das Almas - BA, E-mail: eugenio. coelho@embrapa.br 


\section{INTRODUCTION}

The cultivation of banana tree is significant in agricultural systems in the agro-ecological zones of the tropics (AZEVEDO et al., 2010) with great economic and social importance. In Brazil, the 'Prata', 'Pacovan' and 'Prata-Anã' cultivars are the most widespread. In the Southwest of Bahia (DONATO et al., 2009) and in the North of Minas Gerais, the most planted cultivar is the 'PrataAnã' that despite the high commercial value, it is susceptible to the yellow and black sigatoka, and Panama disease.

In the search of solutions, the Brazilian Program for Banana Plant Improvement, coordinated by Embrapa Mandioca e Fruticultura, developed banana 'Prata' hybrids with different degrees of commercial acceptance.

The physiological characters evaluation may be important for recommending cultivars because it allows establishing a genotypic variation of physiological responses of banana to the environment (TURNER et al., 2007). The existence of this variation would infer on changes in transpiration rates, stomatal conductance and photosynthesis as physiological indicators of the presence of stress (LUCENA, 2013); in addition it contributes to the identification and the selection of superior individuals. The extrapolation of these results may subsidize specific production systems for various cultivars.

Additionally, physiological characteristics studies are quite common in cultivars of Cavendish type (ROBINSON; GÁLAN SAÚCO, 2012), however they are scarce in cultivars of 'Prata' type prevalent in Brazil. Given the above, the aim of this study was to evaluate the physiological characteristics of six 'Prata' type bananas in two production cycles in semi-arid environment.

\section{MATERIAL AND METHODS}

The experiment was established in the area of Instituto Federal Baiano, Campus Guanambi, in the State of Bahia, Brazil. The original soil is classified as typical dystrophic Red-Yellow Latosol, weak A, medium texture, hypoxerophytic caatinga phase, flat to mildly hilly relief, with annual average of precipitation and temperature, $680 \mathrm{~mm}$ and $26^{\circ} \mathrm{C}$ respectively.

In planting, on 05/11/2010, we used seedlings that were acclimatized in plastic bags, $30 \mathrm{~cm}$ tall, and planted in $3.0 \times 2.5 \mathrm{~m}$ spacing. The introduction and cultivation followed the recommendations for the crop (RODRIGUES et al., 2008). The plants were irrigated by micro sprinkling with Netafim $\AA$ self-compensating emitters, flow $120 \mathrm{~L} \mathrm{~h}^{-1}$, wet diameter of $7.4 \mathrm{~m}$, with red nozzle of $1.57 \mathrm{~mm}$, spacing of $6 \mathrm{~m}$ between side lines and $5 \mathrm{~m}$ between emitters.

The irrigations were based on the evapotranspiration reference (ETo) determined daily by the Penman-Monteith method, and on the data from an automatic weather station Vantage Pro Integrated Sensor (Davis Instruments, Wayward, CA, EUA) located $100 \mathrm{~m}$ from the area. The crop coefficients to determine the ETc were defined according to the phenological stages of the crop.

The experimental design was completely randomized, with six treatments represented by 'Prata' type banana cultivars: 'Prata-Anã' (AAB) and the hybrids (AAAB), FHIA-01 ('Maravilha'); FHIA-18; BRS FHIA-18; 'BRS Platina' (PA4244) derivatives from 'Prata-Anã' $x$ M53 (AA); and JV42-135, derivatives from 'Prata de Java' x M53. We used five replications and four plants per plot.

We evaluated the gas exchanges, the leaf temperature and incident radiation on the third or fourth leaf (leaf three or four) counting from the apex to the base, with the help of Lcpro+ ${ }^{\circledR}$ Portable Photosynthesis System (ADC BioScientific Limited, UK) infrared gas analyzer (IRGA), always with the radiation shield facing the sun, with ambient temperature and irradiance, and airflow of $200 \mathrm{ml} \mathrm{min}^{-1}$.

There were 14 monthly evaluations in two reading times, $8 \mathrm{~h}$ and $14 \mathrm{~h}$, covering the period from October 2010 to November 2011, corresponding to the early flowering of the first cycle to the beginning of the harvest of the second production cycle.

We measured the incident radiation in the leaf $\left(Q_{\text {leaf }}\right)$ expressed in $\mu \mathrm{mol}$ photons $\mathrm{m}^{-2} \mathrm{~s}^{-1}$; leaf temperature $\left(T_{\text {leaf }}\right),{ }^{\circ} \mathrm{C}$, internal $\mathrm{CO}_{2}$ concentration $\left(\mathrm{C}_{i}\right), \mu \mathrm{mol} \mathrm{CO} 2 \mathrm{~mol}^{-1}$, stomatal conductance $(\mathrm{gs})$, mol $\mathrm{H}_{2} \mathrm{O} \mathrm{m}^{-2} \mathrm{~s}^{-1}$, transpiration $(E)$, mmol $\mathrm{H}_{2} \mathrm{O}$ $\mathrm{m}^{-2} \mathrm{~s}^{-1}$, net photosynthesis $(A), \mu \mathrm{mol} \mathrm{CO}_{2} \mathrm{~m}^{-2} \mathrm{~s}^{-1}$, instantaneous efficiency of water use $(\mathrm{A} / \mathrm{E}), \mu \mathrm{mol}$ $\mathrm{CO}_{2} \mathrm{~m}^{-2} \mathrm{~s}^{-1} / \mathrm{mmol} \mathrm{H}_{2} \mathrm{O} \mathrm{m}^{-2} \mathrm{~s}^{-1}$, carboxylation efficiency $(\mathrm{A} / \mathrm{C} \mathrm{i})$, quantum efficiency or photochemistry of photosynthesis (A/Qleaf), $\mu \mathrm{mol} \mathrm{CO}_{2} \mathrm{~m}^{-2} \mathrm{~s}^{-1} / \mu \mathrm{mol}$ photons $\mathrm{m}^{-2} \mathrm{~s}^{-1}$.

For statistical analysis of the data of the characteristics evaluated, we adopted the following: a) For the vegetative and yield characteristics, we used six treatments, the cultivars arranged in a randomized design. The data were submitted to variance analysis and the averages compared by Tukey test at $5 \%$ error probability $(\mathrm{p}<0.05)$ 
in SAEG software (SAEG, 2009). b) For the physiological characteristics, we adopted the arrangement in factorial $6 \times 14 \times 2$, six cultivars, 14 evaluation periods (months) and two reading times each period, arranged in a completely randomized design. The data were submitted to analysis of variance and proceeded to the split of interactions according to their significance. The F and Turkey test compared the averages from those variables $(p<0.05)$ for reading time factor and cultivars factor, respectively; and the Skott-Knott criterion grouped them for the evaluation period factor (months). We also realized correlation studies between the different variables and the adjusted linear models for those significant and of greater magnitudes.

\section{RESULTS AND DISCUSSION}

The differences in physiological characteristics evaluated in several months did not allow a grouping of the averages by the ScottKnott criterion $(\mathrm{p}<0.05)$ according to the periods of the year. The grouping was random; probably because of the assessments made with devices are pointwise values, influenced by weather conditions of the moment (SANTOS et al., 2013). These results contradict the expectation of obtaining physiological differences grouped according to the periods, to the two times of reading, which would make it possible to compare the physiological responses of different cultivars in months with similar climatic characteristics.

The physiological variables, leaf temperature $\left(T_{\text {leaf }}\right)$, transpiration rate $(E)$ and instantaneous efficiency of water use $(A / E)$ varied with the cultivar regardless of the month and reading time (Table 1).

The 'BRS Platina' showed higher Tleaf $\left(37.39^{\circ} \mathrm{C}\right)$ and 'Prata-Anã' showed the lower $\left(35.90{ }^{\circ} \mathrm{C}\right)$, with a small percentage variation of $4.15 \%$. The transpiration rate $(E)$ varies similarly to Tleaf, with the higher value $\left(7.04 \mathrm{mmol} \mathrm{H}_{2} \mathrm{O}\right.$ $\mathrm{m}^{-2} \mathrm{~s}^{-1}$ ) measured on the 'BRS Platina' and the lower 6.19; 6.40 and $6.41 \mathrm{mmol} \mathrm{H}_{2} \mathrm{O} \mathrm{m}^{-2} \mathrm{~s}^{-1}$ on the 'PrataAnã', 'Maravilha' and 'FHIA-18', respectively. The instantaneous efficiency of water use $(A / E)$ in leaf was higher $\left(3.45 \mu \mathrm{mol} \mathrm{CO} \mathrm{m}^{-2} \mathrm{~s}^{-1} / \mathrm{mmol} \mathrm{H}_{2} \mathrm{O} \mathrm{m}^{-2} \mathrm{~s}^{-1}\right)$ in the 'Maravilha' and lower $\left(2.96 \mu \mathrm{mol} \mathrm{CO} \mathrm{Cm}^{-2} \mathrm{~s}^{-1} /\right.$ mmol $\mathrm{H}_{2} \mathrm{O} \mathrm{m}^{-2} \mathrm{~s}^{-1}$ ) in the 'BRS Platina'. There is a tendency of direct relation between the $T_{\text {leaf }}$ and $E$ and a contrary relation between the $T_{\text {leaf }}$ and the $A / E$, proven by the correlation study (Figure 1).

The higher $A / E$ observed in 'Maravilha' indicates the highest cultivar efficiency regarding the use of water resource, which is the main obstacle in banana production. Productive efficiency and better use of water do not contradict the recommendation for a new cultivar that requires other desirable characteristics, such as market acceptance despite of the observation meets the research needs to understanding the mechanisms of tolerance to drought (VANHOVE et al., 2012; MUTHUSAMY et al., 2014; KISSEL et al., 2015).

The photosynthetically active radiation incident on the leaf surface (Qleaf), leaf temperature (Tleaf), transpiration rate $(E)$, the instantaneous efficiency of water use $(A / E)$, and the quantum efficiency of photosynthesis $\left(A / Q_{\text {leaf }}\right)$ also varied with periods and reading times regardless of the cultivar (Table 2).

The $Q_{\text {leaf }}$ varied between times in most of the months $(64.28 \%)$ and the higher values were recorded in the morning. Significant changes were observed between the months in the two times of evaluation. The higher value $(1.650,94 \mu \mathrm{mol}$ photons $\left.\mathrm{m}^{-2} \mathrm{~s}^{-1}\right)$ was recorded in February 2011 and the lower $\left(485.65 \mu \mathrm{mol}\right.$ photons $\left.\mathrm{m}^{-2} \mathrm{~s}^{-1}\right)$ was recorded in October 2010 coincident with a cloudy day and presence of rain because it is a typical month of high radiation. The higher value recorded is between the radiation recommended, 1.500 and $2.000 \mu \mathrm{mol}$ photons $\mathrm{m}^{-2} \mathrm{~s}^{-1}$, and the lower value is in the range where photosynthesis is severely reduced, below $1.000 \mu \mathrm{mol}$ photons $\mathrm{m}^{-2} \mathrm{~s}^{-1}$ (TURNER et al., 2007).

The Tleaf recorded in 'Prata' type banana varied between times, in all the evaluated months, regardless of the cultivars, except in January and May 2011 (Table 2).In all cases, the lower Tleaf occurred at $8 \mathrm{~h}$ and the higher occurred in the afternoon, as observed by Donato et al. (2013). Significant differences were also observed between the months in the two times, regardless of the cultivar. The Tleaf had a percentage variation of $43.23 \%$, the lowest value was $30.60{ }^{\circ} \mathrm{C}$ and the highest value was $43.83{ }^{\circ} \mathrm{C}$.

The transpiration rates evaluated in 'Prata' type banana differ between times in every evaluation month, regardless of the cultivar (Table 2), with the occurrence of lower values in the morning and of higher values in the afternoon at $78.57 \%$ of the cases. Variations were also observed between the months in both times, regardless of the cultivar. In October 2010, at $14 \mathrm{~h}$, the lowest transpiration rate was recorded (3.58 $\left.\mathrm{mmol} \mathrm{H}_{2} \mathrm{O} \mathrm{m} \mathrm{m}^{-2} \mathrm{~s}-1\right)$, coincident with cloudy and rainy day illustrated by the lower radiation $\left(485.65 \mu \mathrm{mol}\right.$ photons $\left.\mathrm{m}^{-2} \mathrm{~s}^{-1}\right)$ (Table 2). The highest transpiration $\left(11.96 \mathrm{mmol} \mathrm{H}_{2} \mathrm{O} \mathrm{m}^{-2} \mathrm{~s}^{-1}\right)$ occurred in November 2010 at 14h. 
The efficiency of water use $(\mathrm{A} / \mathrm{E})$ in the leaf of 'Prata' type banana ranged between times in every month except for January 2011 that always presented the higher values in the morning (Table 2) because of the higher photosynthetic rates registered at $8 \mathrm{~h}$ (Table 4) and the lower transpiration (Table 2 ). There was also significant variation between the months in both times.

The photochemical efficiency of photosynthesis represented by the relation between photosynthesis and photosynthetically active radiation $\left(A / Q_{\text {leaf }}\right)$ incident on the third leaf of 'Prata' type banana, showed little variation between the months evaluated at $8 \mathrm{~h}$ (Table 2 ). In the second time the variation was higher. No significant differences were recorded between times in most months.

In all cases, the highest photochemical efficiency was observed at $8 \mathrm{~h}$, except in October 2011. In $\mathrm{C} 3$ plants, the quantum photosynthesis productivity is raised close to $30^{\circ} \mathrm{C}$ and decreases a lot, particularly in banana trees above 34 oC (ROBINSON; GALÁN SAUCO, 2012), which explains the lower quantum efficiency at 14:00 attested by higher leaf temperature values that were measured at this time.

The stomatal conductance ( $g s)$, photosynthetic rate $(A)$ and carboxylation efficiency $(A / C i)$ showed significant interaction $(\mathrm{p}<0.05)$, considering the three factors studied (cultivars, seasons and times), shown in Tables 3, 4, 5, respectively.

All the cultivars showed significant variation in gs between the months and in the two times evaluated (Table 4). The stomatal conductance differed between times in $47.61 \%$ of the cases. These differences were observed for all cultivars in October and November 2010, and in January and May 2011 in most cases, probably because these were the hottest months of the evaluated period (Table 2).

In most of the cases, the highest values of gs occurred in the morning and the lowest in the afternoon, which can be justified by the occurrence of winds in the morning (DONATO et al., 2012) that contributes to the removal of the boundary layer and consequently decreases resistance. The stomatal conductance is the inverse of stomatal resistance to the steam. Its value refers to the potential amount of water that could flow over the leaf surface and it is different from steam flow (or transpiration). The reduction of gs in the afternoon can also be related to the stomatal sensitivity to the air aridity, strongly influenced by temperature. Its values decrease with the increasing of steam pressure deficit and temperature. Factors that influence gs interfere in the acquisition of carbon in plants.

The cultivars did not express differences in gs values in both times every month evaluated, with the exception of November 2010, September and November 2011, at 8h, and November 2011, at $14 \mathrm{~h}$ (Table 5).

Ekanayake et al. (1994) argue the cultivars that restrict the stomatal conductance in drought conditions are considered "water economic." Thus obtaining cultivars with increased tolerance to abiotic stresses passes the identification of characteristics that grants drought tolerance (RAVI et al., 2013) as transpiration efficiency (KISSEL et al., 2015).

It is unlikely that the soil water content may change significantly between measurements, but the leaf steam pressure difference to the air will increase as the temperature increases. Therefore, the variation in stomatal conductance between cultivars is a strategy for the detection of stomatal sensitivity to the steam pressure deficit, which may or may not be related to drought tolerance. Turner et al. (2007), in their review, state that the gas exchange of the leaf is a more sensitive method for determining the response of banana tree to water deficit compared to traditional volumetric or thermodynamic measurements of leaf water status, such as the relative water content.

The change in gas exchange in banana leaves due to the stomatal response to water deficit, steam pressure deficit, leaf temperature and the intensity and quality of solar radiation have been reported in several studies. Different studies show that the stomatal of banana trees can respond to low relative humidity, as well as the reduction of soil moisture, and there is a genetic variation among cultivars, in relation to this feature (EKANAYAKE et al., 1994; THOMAS et al., 1998; KISSEL et al., 2015).

Recorded changes in stomatal conductance (gs) (Table 3), photosynthesis rate $(A)$ (Table 4), carboxylation efficiency $(\mathrm{A} / \mathrm{C} i)$ (Table 5), transpiration rate $(E)$ and efficient use of water $(A / E)$, due to the change of the radiation $\left(Q_{\text {Leaf }}\right)$ and leaf temperature $\left(T_{\text {leaf }}\right)$ (Table 2$)$ were also reported by Donato et al. (2013).

The photosynthetic rate of all cultivars was different between the months in both reading times (Table 4). The values were higher at 8:00 and lower at $14 \mathrm{~h}$ in most months $(66 \%)$, except for the 'PrataAnã' in November 2011 (Table 5).

The cultivars showed the same rate of photosynthesis in each reading time in all evaluation periods, except in October 2010 and in November 
2011, at $8 \mathrm{~h}$, and in June and in November 2011 at 14h (Table 5).

The photosynthetic rate, stomatal conductance (gs) and the efficiency of water use ( $A$ /E), in November 2010, July, August, September and November 2011 were lower at 14:00 than at $8 \mathrm{~h}$, despite subjected to the same radiation $\left(Q_{\text {leaf }}\right)$. Even with the difficulty of separating the effect of the radiation changing $\left(Q_{\text {leaf }}\right)$ and leaf temperature $\left(T_{\text {leaf }}\right)$ in gas exchange in field experiments (LUCENA, 2013), the present study data allow us to state that the decrease in rates, observed at $14 \mathrm{~h}$, is the reflection of increasing temperature, as observed by Donato et al. (2013). The leaf temperature varied a percentage of $43.23 \%$, the highest value, $43.83{ }^{\circ} \mathrm{C}$ recorded in November 2010 at $14 \mathrm{~h}$, to the lowest, $30.60{ }^{\circ} \mathrm{C}$, in September 2011 at $8 \mathrm{~h}$ (Table 2).

The rise in temperature increases evapotranspiration demand and directly influences all metabolic and physiological processes of the plant. Probably, the rise in temperature affects the functioning of the enzyme system at a higher intensity than the stomatal closure because the transpiration rate $(E)$ increased at $14 \mathrm{~h}$ for all cultivars in most of the months (Table 2). However, the ecophysiological behavior results from the balance of the various environmental factors (DONATO et al., 2013). This is also proven by the decrease of $\mathrm{A} / \mathrm{E}$ and the increase of the transpiration on linear basis with the increase of temperature (Figure 1). If transpiration increased, logically there would not be stomatal restriction.

The ratio $\mathrm{A} / \mathrm{Ci}$ is a measure of the rubisco carboxylation efficiency and its decrease expresses a shift toward oxygenized activity. This characteristic varies between months, in both times for all cultivars (Table 5). The relation $\mathrm{A} / \mathrm{Ci}$ of the cultivars was similar between reading times, in most of the evaluation months (60.72\%). In $39.28 \%$ of the cases, the values were always higher at 8:00 and lower at $14 \mathrm{~h}$, except for the 'BRS Platina' in December 2010. Proof of the Rubisco carboxylase activity change to oxygenize, with the temperature increase observed from $8: 00$ to $14: 00$, is in the reduction of ration between photosynthesis and internal $\mathrm{CO}_{2}$ concentration $(\mathrm{A} / \mathrm{Ci})$ observed in $39.28 \%$ of the cases. Considering the percentage difference, regardless of differences detected by the Tukey test $(\mathrm{p}<0.05)$, they increase this variation to $67.85 \%$ for all cultivars and months.

The cultivars evaluated showed similar A/ $\mathrm{Ci}$ relation. The averages did not differ between the evaluated times and month, except in October 2010 and June 2011 (Table 5). The highest value (0.13 $\mu \mathrm{mol} \mathrm{CO} \mathrm{m}^{-2} \mathrm{~s}^{-1} / \mu \mathrm{mol} \mathrm{CO} \mathrm{mol}^{-1}$ ) was recorded in 'BRS Platinum' in January 2011 at $8 \mathrm{~h}$ and the lowest $\left(0.04 \mu \mathrm{mol} \mathrm{CO} \mathrm{m}^{-2} \mathrm{~s}^{-1} / \mu \mathrm{mol} \mathrm{CO} 2 \mathrm{~mol}^{-1}\right)$ in JV42-135 evaluated in February and May 2011 at $14 \mathrm{~h}$. This relation may clarify the factors that limit the photosynthesis, analyzing the adjusted curve of $\mathrm{A} / \mathrm{Ci}$.

The great temperature for carboxylation of the prevailing $\mathrm{CO}_{2}$ in plants with $\mathrm{C}_{3}$ photosynthetic mechanism, such as the banana, is around 22 ${ }^{\circ} \mathrm{C}$, while the great temperature for growth and development is approximately $27^{\circ} \mathrm{C}$ (ROBINSON; GALÁN SAÚCO, 2012). The balance between carboxylase and oxygenize activities of Rubisco is ruled by its kinetics, temperature and concentration of $\mathrm{CO}_{2}$ and $\mathrm{O}_{2}$ substrates. Under environmental $\mathrm{CO}_{2}$ concentration, the increase in temperature modifies the kinetic constants of rubisco, and increases oxygenation rate preferably to carboxylation, consequently increases photorespiration and decreases net photosynthesis.

The plant can respond differently to environmental conditions, proved by the maintenance of the photosynthesis rate $(A)$ (Table 4) and stomatal conductance $(g s)$ (Table 3 ), in the evening, most of the cultivars, in December 2010, March, April and June 2011. Despite the increase in leaf temperature $\left(T_{\text {leaf }}\right)$, the transpiration rate $(E)$ and the reduction in water use efficiency $(A / E)$ (Table 2 ), we did not observe decrease in carboxylation efficiency $(\mathrm{A} / \mathrm{C} \mathrm{i})$ at $14 \mathrm{~h}$ for most cultivars, which shows the greatest effect on the intensity of the radiation (Qleaf) in gas exchange.

Seneviratne et al. (2008) also found a reduction in photosynthesis rate when the radiation level decreased while studying the different levels of shading and Photoinhibition under conditions of high intensity of light. Probably the same happened in this study, in February 2011, when all cultivars were subjected to a higher radiation Qleaf (1650.94 $\mu \mathrm{mol}$ photons $\mathrm{m}^{-2} \mathrm{~s}^{-1}$ ) at $8 \mathrm{~h}$ they had minor photosynthetic rates for the period, except the 'Prata-Anã' (Table 4).

The photosynthesis rate is increased by the presence of growth organs in the plant and reduced with the increase of shadowing or senescence (age) of the leaf. The lowest value of $\mathrm{A}\left(8.28 \mu \mathrm{mol} \mathrm{CO} \mathrm{m}^{-2} \mathrm{~s}^{-1}\right)$ was recorded in May 2011 at 14h in JV42-135 and the highest $\left(27.10 \mu \mathrm{mol} \mathrm{CO}_{2} \mathrm{~m}^{-2} \mathrm{~s}^{-1}\right)$ recorded in January 2011 at $8 \mathrm{~h}$ in 'Maravilha'. The photosynthesis showed a variation of $227.29 \%$, proving that the photosynthetic rates of banana trees can reach values of 25 to $30 \mu \mathrm{mol} \mathrm{CO} \mathrm{m}^{-2} \mathrm{~s}^{-1}$ (TURNER et al., 2007; ROBINSON; GÁLAN SAÚCO, 2012). 
The studied cultivars expressed the same photosynthetic rate at $8 \mathrm{~h}$ and $14 \mathrm{~h}$ on all evaluated months, with the exception of October 2010 at $8 \mathrm{~h}$, June 2011 at $14 \mathrm{~h}$ and November 2011 at $8 \mathrm{~h}$ and $14 \mathrm{~h}$ (Table 4).

Several authors established associations between gas exchange of plants and the weather. Field studies reveal the integrated effects of environmental conditions on the physiology of banana trees, so correlations between these answers and climatic factors indicate trends, since there is influence of unmeasured factors. Higher precision in the associations between gas exchange and climatic factors is obtained in environments with controlled conditions (ROBINSON; GÁLAN SAÚCO, 2012). Nevertheless, Vanhove et al. (2012) state that experiments conducted in vitro and in greenhouse increase the experimental control, but it has lower physiological relevance compared to field studies.

The banana trees type 'Prata' presented, in November 2010, higher photosynthetic rates, stomatal conductance and transpiration compared to other months, regardless of the cultivar. The higher transpiration values $(E), 10.11$ and 11.96 mmol $\mathrm{H}_{2} \mathrm{O} \mathrm{m}-{ }^{2} \mathrm{~s}^{-1}$, in the two times, $8 \mathrm{~h}$ and $14 \mathrm{~h}$, respectively, were due probably to the higher volume of rainfall recorded in the month $(276.50$ $\mathrm{mm}$ ) that consequently increased soil moisture. The maximum Tleaf, $39.23^{\circ} \mathrm{C}$ and $43.83^{\circ} \mathrm{C}$, observed at $8 \mathrm{~h}$ and $14 \mathrm{~h}$, respectively, are a result of the ambient temperature above $34{ }^{\circ} \mathrm{C}$, stressful for the banana tree (ROBINSON; GÁLAN SAÚCO, 2012), as well as the second highest radiation level $\left(Q_{\text {leaf }}\right) 1298.11 \mu \mathrm{mol}$ photons $\mathrm{m}^{-2} \mathrm{~s}^{-1}$ and 1212.36 $\mu \mathrm{mol}$ photons $\mathrm{m}^{-2} \mathrm{~s}^{-1}$ recorded in the morning and afternoon respectively. The high transpiration rates illustrate the plant cooling mechanism to relieve the heat stress caused by higher soil moisture.

The correlation study between the variables showed direct association, significant and of high magnitude, only between the rate of transpiration and leaf temperature of banana trees type 'Prata' cultivated in semi-arid environment (Figure 1). The adjusted linear models estimate an increase of $0.70 ; 0.47 ; 0.48 ; 0.42 ; 0.50$ and 0.44 units in transpiration for each additional unit on the leaf temperature of cultivars 'Maravilha', BRS FHIA18, FHIA-18, BRS Platina, 'Prata-Anã' and JV42135 respectively.

The correlation study also established an inverse association, significant and high magnitude, only between the relation $\mathrm{A} / \mathrm{E}$ and the Tleaf (Figure $1)$. The adjusted linear regression models predict a decrease of $0.26 ; 0.26 ; 0.37 ; 0.32 ; 0.29$ and 0.28 units in the relation $(\mathrm{A} / \mathrm{E})$ for each increase of one unit in Tleaf in the cultivars 'Maravilha ', BRS FHIA-18 ',' FHIA-18 ',' BRS Platinum ',' PrataAnã' and JV42-135 respectively.

The increase in leaf temperature, due to the air temperature rise, increases transpiration and reduces water use efficiency for all crops, as reported by Donato et al. (2013). Changes in transpiration rates show stomatal opening as a cooling mechanism and showed that the reduction in photosynthetic rates in warmer times was more influenced by enzymatic involvement caused by temperature increase than by stomatal closure.

Lucena (2013) found a high, positive and significant correlation $(p<0.05)$ between transpiration and the air temperature to 'BRS Platina' and 'Prata-Anã'. The author also found a high correlation, inverse and significant $(p<0.05)$ between the $\mathrm{A} / \mathrm{E}$ and the air temperature. In his study, without water limitation, 'BRS Platinum' and 'Prata-Anã' had the same productivity $(14,375$ $\left.\mathrm{kg} \cdot \mathrm{ha}^{-1}\right)$ in the first cycle and maximum values for the next 20.6 and $22.2 \mu \mathrm{mol} \mathrm{CO} \mathrm{m}^{-2} \mathrm{~s}^{-1}$, respectively. In this study under the same conditions (local, level, population, spacing and original soil class), but with higher soil fertility and better management of plants, the maximum values of A for 'BRS Platinum' and 'Prata-Anã 'were higher, 26.44 and $25.52 \mu \mathrm{mol}$ $\mathrm{CO}_{2} \mathrm{~m}_{-2} \mathrm{~s}_{-1}$, respectively. The yield in the first cycle was higher, 25.4 and 21.3 t.ha $^{-1}$, respectively.

For DaMatta (2007), the reduction of production is associated with a decline in photosynthetic rates induced by low water availability in the soil, either by a direct effect of dehydration in the photosynthetic apparatus or by an indirect effect through stomatal closure, which restricts the absorption of $\mathrm{CO}_{2}$. Santos et al. (2013) evaluated 'Tommy Atkins' mangos under different irrigation regimes in the same region of this study and concluded that the gas exchange influenced the growth, development and production and they were related to water conditions of the plant, depending on the soil water status and weather conditions.

The showed data highlight the significant influence of temperature on gas exchange, either in a direct way with protein denaturation or indirectly by the sensitivity of stomatal to the effect of steam pressure deficit. However, correlations between these characteristics are not always found. 

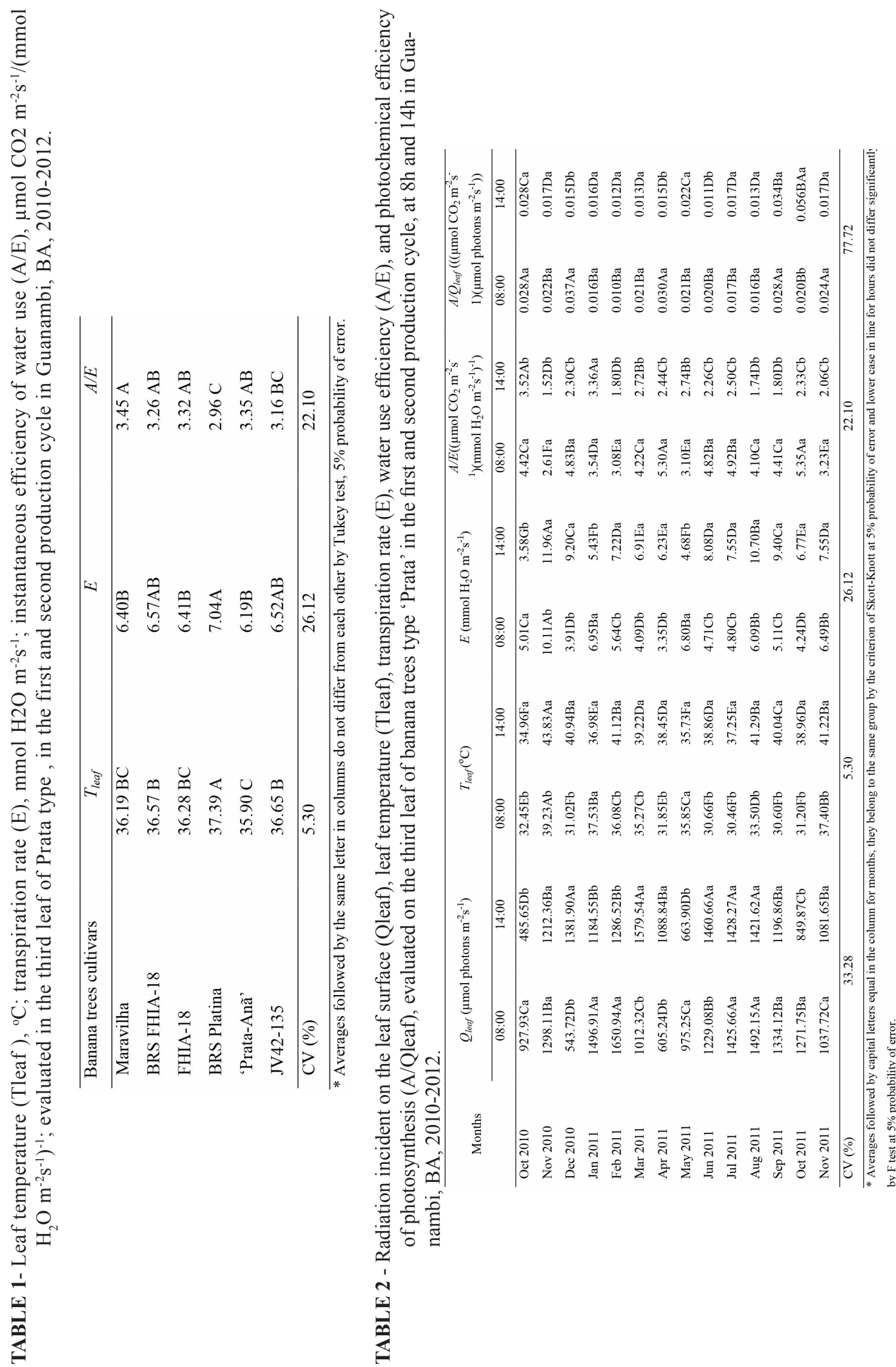


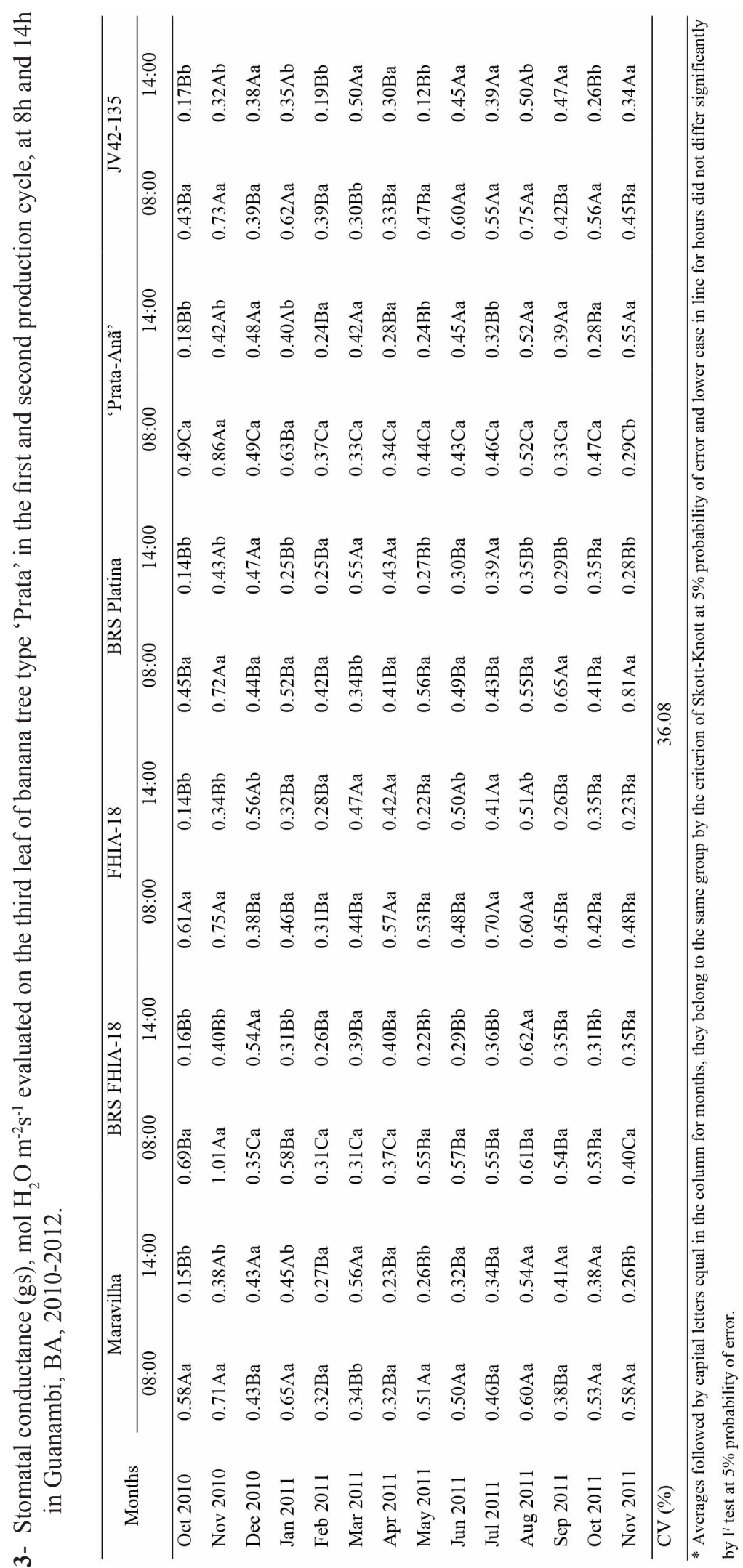




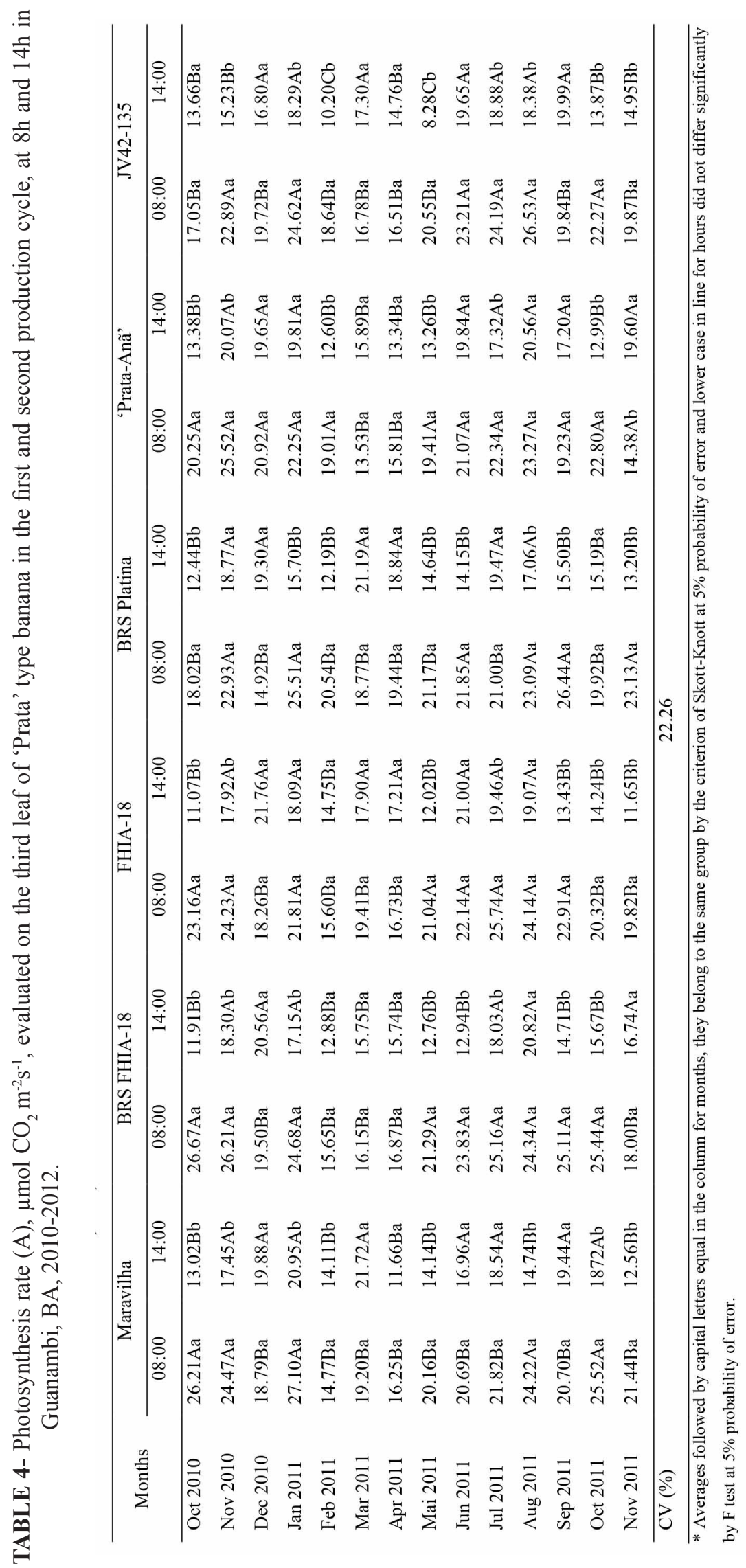




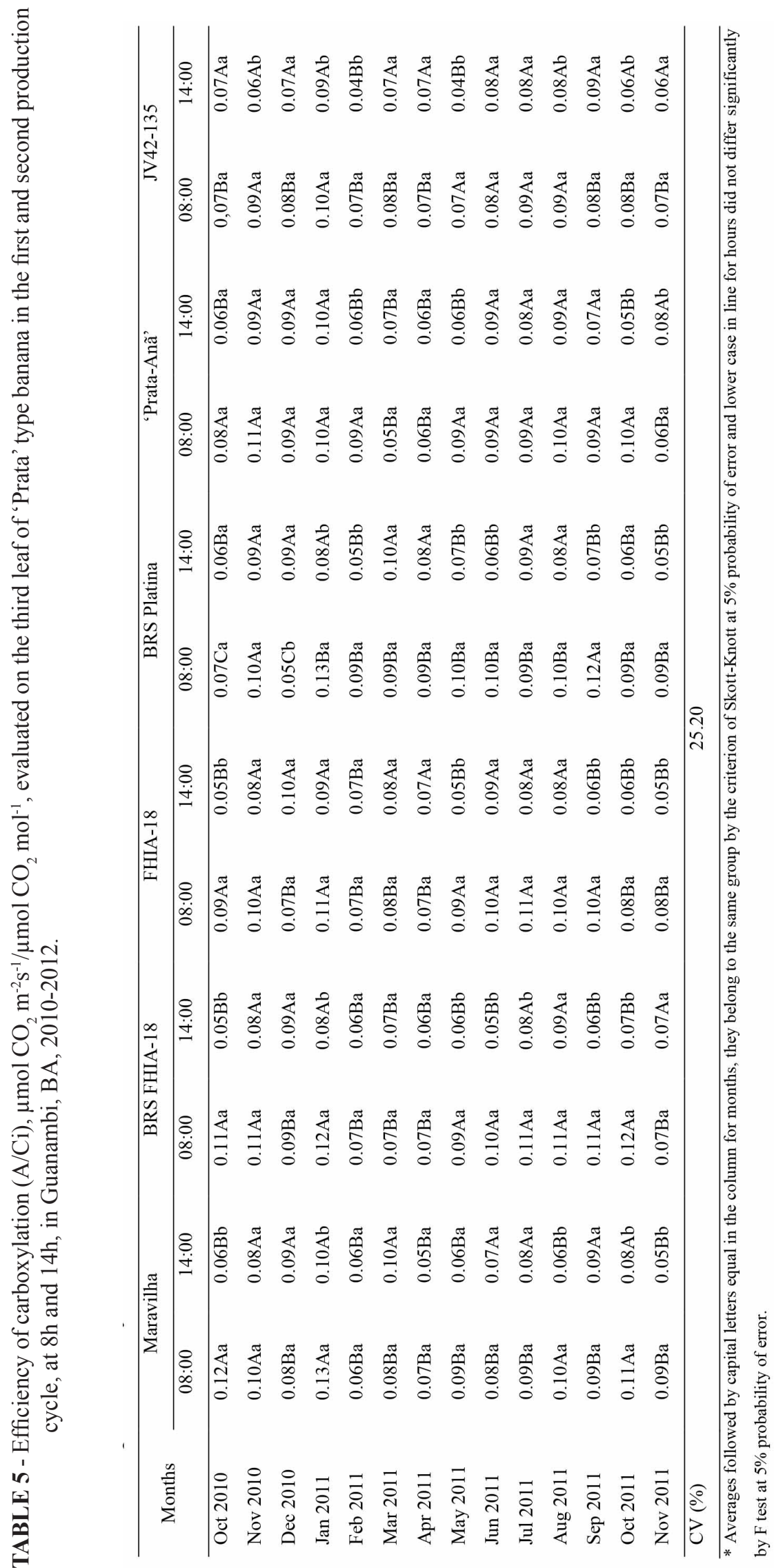




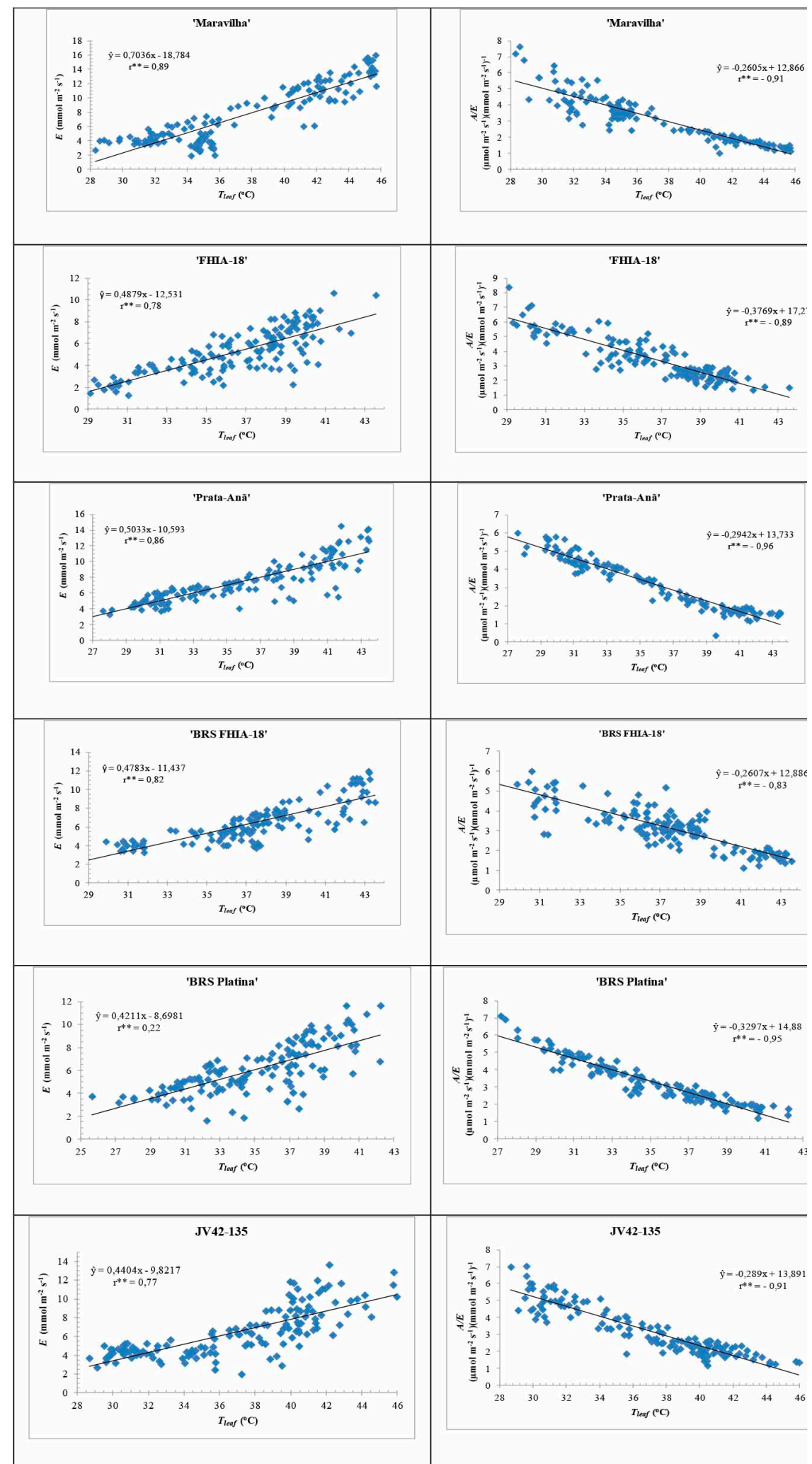

FIGURE 1- Correlation between transpiration rate (E), $\mathrm{mmol} \mathrm{H}_{2} \mathrm{O} \mathrm{m}^{-2} \mathrm{~s}^{-1}$, and leaf temperature (Tleaf), ${ }^{\circ} \mathrm{C}$, and between the instantaneous efficiency of water use $(\mathrm{A} / \mathrm{E}), \mu \mathrm{mol} \mathrm{CO}_{2} \mathrm{~m}^{-2} \mathrm{~s}^{-1} /(\mathrm{mmol}$ $\left.\mathrm{H}_{2} \mathrm{O} \mathrm{m}^{-2} \mathrm{~s}^{-1}\right)^{-1}$, and the leaf temperature (Tleaf), ${ }^{\circ} \mathrm{C}$, evaluated in the third leaf of 'Prata' type banana, in the first and second production cycle in Guanambi, BA, 2010-2012. 


\section{REFERENCES}

AZEVEDO, V.F.; DONATO, S.L.R.; ARANTES, A.M.; MAIA, V.M.; SILVA, S.O. Avaliação de bananeiras tipo prata, de porte alto, no semiárido. Ciência e Agrotecnologia, Lavras, v.34, p.1372$1380,2010$.

DAMATTA, F.M. Ecophysiology of tropical tree crops: an introduction. Brazilian Journal Plant Physiology, Londrina, v.19, p.239-244, 2007.

DONATO, S.L.R.; ARANTES, A.M.; SILVA, S.O.; CORDEIRO, Z.J.M. Comportamento fitotécnico da bananeira 'Prata-Anã' e de seus híbridos. Pesquisa Agropecuária Brasileira, Brasília, v.44, p.1508$1515,2009$.

DONATO, S.L.R.; COELHO, E.F.; ARANTES, A.M.; COTRIM, C.E.; MARQUES, P.R.R. Relações hídricas I: Considerações fisiológicas e ecológicas. In: COELHO, E.F. (Org.). Irrigação da bananeira. Brasília: Embrapa, 2012. p.85-117.

DONATO, S.L.R.; COELHO, E.F.; MARQUES, P.R.R.; ARANTES, A.M.; SANTOS, M.R.; OLIVEIRA, P.M. Ecofisiologia e eficiência de uso da água em bananeira. In: REUNIÃOINTERNACIONAL DA ASSOCIAÇÃO PARA A COOPERAÇÃO EM PESQUISA E DESENVOLVIMENTO INTEGRAL DAS MUSÁCEAS (BANANAS E PLÁTANOS), 20., 2013, Fortaleza. Anais... Cruz das Almas: Embrapa Mandioca e Fruticultura, 2013. p.58-72.

EKANAYAKE, I.J.; ORTIZ, R.; VUYLSTEKE, D.R. Influence of leaf age, soil moisture, VPD and time of day on leaf conductance of various Musa genotypes in a humid forest-moist savanna transition site. Annals of Botany, London, v.74, p.173-178, 1994.

KISSEL, E.; VAN ASTEN, P.; SWENNEN, R.; LORENZEN, J.; CARPENTIER, S.C. Transpiration efficiency versus growth: Exploring the banana biodiversity for drought tolerance. Scientia Horticulturae, Amsterdam, v.185, n., p.175-182, 2015. Disponível em: $<\mathrm{http}: / / \mathrm{dx}$. doi.org/10.1016/j. scienta.2015.01.035>.

LUCENA, C.C. Estratégias de manejo de irrigação de bananeiras baseadas em coeficientes de transpiração e área foliar. 2013. 152 f. Tese (Doutorado) - Universidade Federal de Viçosa, Viçosa, 2013.
MUTHUSAMY, M.; UMA, S.; BACKIYARANI, S.; SARASWATHI, M.S. Computational prediction, identification, and expression profiling of microRNAs in banana (Musa spp.) during soil moisture deficit stress. The Journal of Horticultural Sciences \& Biotechnology, Ashford, v.89, n.2, p.208-214, 2014.

RAVI,I.; UMA, S.; VAGANAM, M.M.; MUSTAFFA, M.M. Phenotyping bananas for drought resistance. Frontiers in physiology, Ohio, v.4, n.1, p.1-15, 2013.

ROBINSON, J.C.; GÁLAN SAÚCO, V. Plátanos y bananos. 2nd ed. España: Ediciones Mundi-Prensa, 2012. 321p

RODRIGUES, M.G.V.; DIAS, M.S.C.; RUGGIERO, C.; LiCHTEMBERG, L.A. Planejamento, implantação e manejo do bananal. Informe Agropecuário, Belo Horizonte, v. 29, n. 245, p. 14-22, 2008.

SAEG. Sistemas para análises estastísticas. Versão 9.1. CD-ROM. Viçosa: FUNARB, UFV, 2007. CDROM.

SANTOS, M.R; MARTINEZ, M.A.; DONATO, S.L.R. Gas exchanges of Tommy Atkins mango trees under different irrigation treatments. Bioscience Journal, Uberlândia, v. 29, p. 1141-1153, 2013.

SENEVIRATHNA, A.M.W.K.; STIRLING, C.M.; RODRIGO, V.H.L. Acclimation of photosynthesis and growth of banana (Musa sp.) to natural shade in the humid tropics. Experimental Agriculture, Cambridge, v.44, p.301-312, 2008.

THOMAS D.S.; TURNER D.W.; EAMUS, D. Independent effects of the environment on the leaf gas exchange of three banana (Musa sp.) cultivares of different genomic constitution. Scientia Horticulturae, New York, v.75, p.41-57, 1998.

TURNER, D.W.; FORTESCUE, J.A.; THOMAS, D.S. Environmental physiology of the bananas (Musa spp.). Brazilian Journal Plant Physiology, Londrina, v.19, p.463-484, 2007.

VANHOVE, A.C.; VERMAELEN, W.; PANIS, B.; SWENNEN, R.; CARPENTIER, S.C. Screening the banana biodiversity for drought tolerance: can an in vitro growth model and proteomics be used as a tool to discover tolerant varieties and understand homeostasis. Frontiers in Plant Science, Lausanne, v.3, p.1-10, 2012 . 